\title{
BIOPHOTONICS FOR BIOFUEL UPGRADATION
}

\author{
Gopinath RANA \\ Madhyapradesh, India \\ Tanusri MANDAL \\ Vidyasagar University, West Bengal, India
}

\begin{abstract}
:
Experimental studies have been made to find out Cyanobacterias' biophotonical response in gaseous-fuelation and carbon dioxide fixation during photo-anaerobic digestion. A new horizontal type photo-bioreactor has been designed by using environment hazard plastic bottles and it works ideally for anoxygenic cyanobacterial growth. Through 'V3metagenomics' of $16 \mathrm{~S}$ rRNA gene sequencing by paired-end Illumina MiSeq and downstream analysis by QIIME program, we have identified anaerobic cyanobacteria, represent the orders YS2 and Streptophyta. OTUs have been identified by aligning against Greengenes and Silva databases, separately. The flame temperature of the fuel gas is $860^{\circ} \mathrm{C}$ and the percent-content of carbon dioxide $\left(\mathrm{CO}_{2}\right)$ is $17.6 \%$
\end{abstract}

Key words: cyanobacteria, photo-anaerobic digestion, $\mathrm{CO}_{2}$ fixation, gaseous fuels, V3-metagenomics

\section{INTRODUCTION}

Biogas generation technology is one of the most potential technologies of renewable bio-energy generation from biodegradable waste materials through anaerobic digestion [1]. Thus biogas production by anaerobic digestion has a great impact on the crop production, waste management, control of odors and energy production [2]. In anaerobic digestion process, different types of bacteria (like; hydrolytic, acidogenic and methanogenic) can convert biodegradable organic wastes into high calorific fuel gases, likehydrogen, methane, other hydrocarbon gases [1]. Biogas can also be used in running vehicles after it has been cleaned and upgraded [3]. The cleaning is done by separation of water vapour $\left(\mathrm{H}_{2} \mathrm{O}\right)$, hydrogen sulphide $\left(\mathrm{H}_{2} \mathrm{~S}\right)$, ammonia $\left(\mathrm{NH}_{3}\right)$ and sulphur dioxide $\left(\mathrm{SO}_{2}\right)$, while upgradation is done by reducing the amount of carbon dioxide $\left(\mathrm{CO}_{2}\right)$ and carbon monoxide (CO) present in the biogas mixture. Modern biogas cleaning and upgradation technologies are based on percent improvement of methane and higher hydrocarbons content within the biogas mixture by adopting different techniques like, enzymatic hydrolysis [4], utilization of different types of cattle manures [5], utilization of different feedstock/food waste $[1,6]$, microwave heating [7], metal catalyst use [8] and ultimately utilization of 2 different types of microorganisms [9]. Higher percent of methane increases the calorific value of biogas [1]. A high quality biogas with high flame temperature can be used as next generation fuel and clean energy. Normal biogas (55-60\% methane) has a flame temperature of approximately $700^{\circ} \mathrm{C}[10]$. This phenomenon indicates that high methane enumerated biogas burns with high flame temperature [3].

There is a great interest in analyzing the structure and function of microbial communities residing in biogas- producing unit. Now a day, environmental microbial communities are studied by construction of 16S-rDNA clone libraries and subsequent sequencing of individual 16rDNAclones [11]. In addition to the 16S-rDNA, other marker genes (such as; mcrA encoding the $\alpha$-subunit of the methanogenesis enzyme methyl coenzyme- $M$ reductase have been used to elucidate the composition of methanogenic consortia) amplification by the selection of PCR primers is also being adopted for microbial community study [12]. The metagenome study in community structure analysis is now a new area to the microbiologists [1]. Biogas-producing microbial community structure analysis from a productionscale biogas plant revealed that Clostridia from the phylum Firmicutes is the most prevalent taxonomic class, whereas species of the order Methanomicrobiales are dominant among methanogenic Archaea. Thus the genus Methanoculleus play a dominant role in methanogenesis. This hydrolysis step is mainly monitored by cellulolytic Clostridia and Bacilli [13].

Then sugar intermediates are fermented to organic acids (acidogenesis) which are finally converted to acetate, $\mathrm{CO}_{2}$ and $\mathrm{H}_{2}$. The final methanogenesis step is carried out by methanogenotropic Archaea community. Hydrolysis and acidogenesis may also be conducted by Eubacteria, but several biochemical reactions are thermodynamically only possible in close interaction of at least two different bacterial genus.

Cyanobacteria are structurally different from Gramnegative phototrophic bacteria as they have both algal as well as bacterial properties but they perform oxygenic/ anoxygenic photosynthesis [14].

Many cyanobacteria are obligate phototrophs, being wholly incapable of dark growth at the expanse of organic source of carbon and energy. Oscillatoria limnetica is capa- 
ble of anaerobic, sulphide dependent photo-assimilation of carbon dioxide [15]. Rana et al. (2014) has been reported that fresh cow dung is a good source of different cyanobacterial species [16]. In this experimental work, an attempt has been taken to generate high calorific fuel gas by cyanobacterial population present in fresh cow dung through photo-anaerobic digestion.

\section{MATERIALS AND METHODS}

Designing of laboratory scale anaerobic photo-bioreactor

The experimental set up consists of the following major components (Fig. 1): (i) bench-type anaerobic digesters (600 $\mathrm{ml}$ capacity transparent plastic bottles) arranged in batch mode; (ii) $2 \mathrm{~L}$ capacity plastic bottles as gas collector attached with a $300 \mathrm{ml}$ plastic bottle for water-pressure maintenance; (iii) rubber-pipes for different outlet and inlet connections.

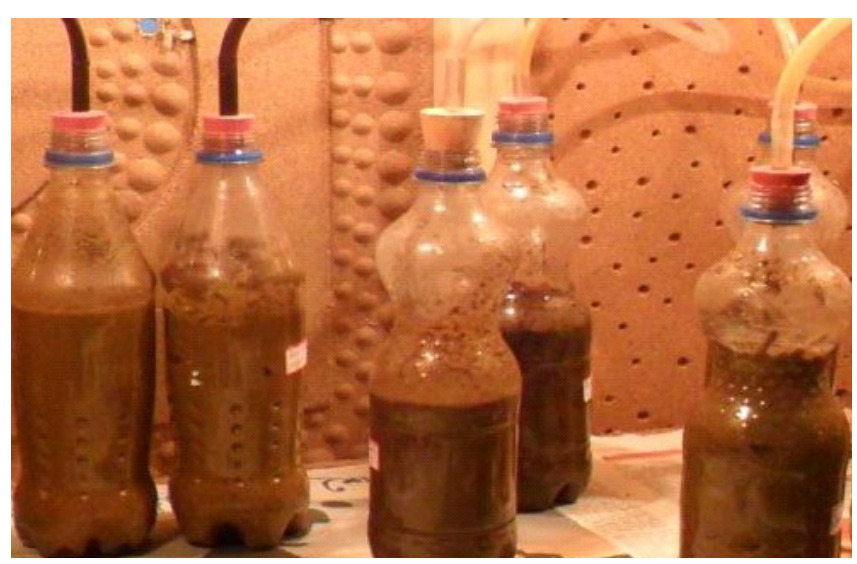

Fig. 1 Bench type photo-bioreactors are arranged in batch mode

Bacterial community study from Pringsheim's broth (PB)

Fresh cow dung (FCD) has been collected from local dairy of Paschim Medinipur, West Bengal, India (Latitude$22^{\circ} 25^{\prime} 00^{\prime \prime}$ to $22^{\circ} 57^{\prime} 00^{\prime \prime}$ north, Longitude $-87^{\circ} 11^{\prime}$ east, Altitude - 23 meters from mean sea level). 1gm FCD has been dumped in $100 \mathrm{ml}$ Pringsheim's broth (PB) [Medium composition in gm/liter: $\mathrm{KNO}_{3} 0.08 ; \mathrm{MgSO}_{4} \cdot 7 \mathrm{H}_{2} \mathrm{O} 0.004 ;\left(\mathrm{NH}_{4}\right)$ $2 \mathrm{HPO}_{4}$ 0.008; $\mathrm{CaCl}_{2} \cdot 2 \mathrm{H}_{2} \mathrm{O} 0.002 ; \mathrm{FeCl}_{3}$ 0.0002] [17] and incubated at $37 \pm 2^{\circ} \mathrm{C}$. After two weeks, $350 \mathrm{ml}$ PB screening media has been pre-filtered through $\sim 1.5 \mathrm{~mm}$ filter paper (Whatman) and then bacterial cells have been collected on a bacterial filter membrane ( $0.22 \mu \mathrm{m}$ pore size, HIMEDIA). Total community DNA of that sample has been extracted according to Webb and Mass protocol (2011) [18]. 16S rRNA genes have been PCR amplified using the primers $27 \mathrm{~F}$ (5'-AGAGTTTGATCCTGGTCAGAACGCT-3') and 1492R (5'TACGGCTACCTTGTTACGACTTCACCCC-3') and the conditions described previously [1]. $5 \mathrm{ng}$ of total 16S rRNA gene amplicons have been sequenced by using Illumina MiSeq sequencer (providing paired-end reads with an average length $151 \mathrm{bp}$. 16S rRNA amplicons have been sequenced for metagenome analysis using primers $341 \mathrm{~F}$ CCTACGGGAGGCAGCAG-3') and 518R (5'ATTACCGCGGCTGCTGG-3'). Each $25 \mu \mathrm{l}$ PCR mixture comprise of $2 \mu \mathrm{l}$ each $10 \mathrm{pmol} / \mu \mathrm{l}$ forward and reverse primers, 0.5 $\mu \mathrm{l}$ of $40 \mathrm{mM}$ dNTPs, $5 \mu \mathrm{l}$ of $5 \mathrm{X}$ Phusion HF reaction buffer, $0.2 \mu \mathrm{l}$ of $2 \mathrm{U} / \mu \mathrm{l}$ F-540 Special Phusion HS DNA Polymerase (Invitrogen), $5 \mathrm{ng}$ input DNA and nuclease-free water. PCR conditions consist of $30 \mathrm{sec}$ incubation at $98^{\circ} \mathrm{C}$ followed by 30 cycles of $98^{\circ} \mathrm{C}, 10 \mathrm{sec} ; 72^{\circ} \mathrm{C}, 30 \mathrm{sec}$; and $72^{\circ} \mathrm{C}, 5 \mathrm{~min}$.
Two separate PCRs have been carried out for universal 'V3primers' (341F and 518R) and primers with Illumina bar code sequences. Amplicons size selection has been carried out using Gel Extraction and the expected band should be between 230 to $250 \mathrm{bp}$.

Before starting the analysis, singletons (due to sequencing errors) are removed to get spurious OTUs. Chimeras are also removed using the de-novo chimera removal method UCHIME implemented in the tool USEARCH. QIIME (quantitative insights into microbial ecology) software package, version 1.8.0 was used for the entire downstream analysis [19]. Then, taxonomic classification has been performed using RDP classifier and Greengenes as well as Silva OTUs database.

\section{Preparation of slurry and parameter analysis}

Cow dung slurry has been prepared and all the required parameters have been assayed followed by Rana et al. (2017) [1]. A $300 \mathrm{ml}$ of the prepared cow dung slurry has been autoclaved at $15 \mathrm{lb} /$ inch $^{3}$ pressure for $15 \mathrm{~min}$. Then that autoclaved-cow dung slurry has been mixed with $50 \mathrm{ml}$ screened PB media. $\mathrm{pH}$ and percentage of hydrogen $\left(\mathrm{H}_{2}\right)$, methane $\left(\mathrm{CH}_{4}\right)$ and carbon dioxide $\left(\mathrm{CO}_{2}\right)$ gases have been measured by following Rana et al. (2017) [1].

\section{Volatile fatty acids analysis in the fermented broth}

The VFAs profile of the fermented broth has been determined by Gas chromatography (GC Agilent Technology 7890A U.S.A) equipped with a flame ionization detector (FID) and capillary column coated with $10 \%$ PEG-20M and $2 \% \mathrm{H}_{3} \mathrm{PO}_{4}(80 / 100$ mesh). The temperature of the injection port, detector and programmed column are $220^{\circ} \mathrm{C}, 240^{\circ} \mathrm{C}$ and $130^{\circ} \mathrm{C}-175^{\circ} \mathrm{C}$, respectively. A mixture of hydrogen and air at a flow rate of $30 \mathrm{~mL} \cdot \mathrm{min}^{-1}$ has been used for flame generation [20].

\section{RESULTS}

Potentiality assessment of newly designed photo-bioreactor

The newly designed photo-anaerobic digesters are made of environmental hazard materials like waste plastic mineral water bottles and used pipes. Transparency character of the plastic bottles facilitates in microbial photoanaerobic growth and photosynthesis in presence of artificial light.

Digesters are bench-type and have been used in batch mode (Fig. 1). Anaerobic condition can be securely maintained with in this type of photo-anaerobic digester. Cyanobacteria are autotrophs and show desirable growth inside the bioreactor. Anaerobic digestion by cyanobacterial isolates and their biofuelation by consuming cow-dung have been successfully carried out by using these digesters.

High flame temperature of the product fuel gas proves digesters anaerobic condition maintenance ability.

Identification of anaerobic cyanobacterial population screened by $P B$ broth

Metagenome analysis of PB screened culture media has been carried out by applying highthroughput sequencing technology (Illumina micro-sequencing). The microbial ecology of the anaerobic PB has been studied by 'V3-pipeline' sequencing of $16 \mathrm{~S}$ rRNA. Usually a paired-end sequence from 'V3-Metagenomics' contains some portion of conserved region, spacer and 'V3 region'. As a first step we remove the spacer and conserved region from paired-end reads. 
Table 1

Read Summary

\begin{tabular}{cccccc}
\hline $\begin{array}{c}\text { Sample } \\
\text { Name }\end{array}$ & Total Reads & $\begin{array}{c}\text { Passed Conserved } \\
\text { Region Filter }\end{array}$ & $\begin{array}{c}\text { Passed } \\
\text { Spacer }\end{array}$ & $\begin{array}{c}\text { Passed Read } \\
\text { Quality Filter }\end{array}$ & $\begin{array}{c}\text { Passed Mismatch } \\
\text { Filter }\end{array}$ \\
GR-2-1 & $511,105(100.00 \%)$ & $478,545(93.63 \%)$ & $478,254(93.63 \%)$ & $478,087(93.54 \%)$ & $192,710(37.70 \%)$ \\
\hline
\end{tabular}

Table 2

Pre-processing reads statistics

\begin{tabular}{cccc}
\hline Sample & Consensus Reads & Chimeric Sequences & Pre-processed Reads \\
GR-2-1 & $192,710(100.00 \%)$ & $6,043(3.14 \%)$ & $186,667(96.86 \%)$ \\
\hline
\end{tabular}

After trimming the unwanted sequences from original paired-end data a consensus ' $\mathrm{V} 3$ region' sequence is constructed using 'ClustalW program'. We apply multiple filters such as, conserved region filter, spacer filter and mismatch filter are performed to take further only the high quality $\mathrm{V} 3$ region sequences for various downstream analyses. While making consensus V3 sequence, more than $80 \%$ of the paired-end reads aligned to each other with 0 mismatches with an average 'contig length' of $\sim 135$ to $165 \mathrm{bp}$. A summary of reads that passed each filter can be found in Table 1.

Pre-processing of reads: chimera filter

We have performed the following pre-processing steps before we start the analysis. Chimeras were also removed using the de novo chimera removal method 'UCHIME implemented in the tool USEARCH'. A detailed table of singleton removal and chimera filter based on individual sample is given in Table 2. These sequences have been taken for OTU identification.

OTUs and Taxonomy classification and relative abundance

This analysis was performed using the pre-processed consensus V3 sequences. Pre-processed

reads were clustered into Operational Taxonomic Units (OTUs) based on their sequence similarity using 'Uclust program' (similarity cutoff $=0.97$ ). A total of 4,361 OTUs were identified from 186,667 reads. OTUs with only one read in it were identified as Singletons OTUs and those were removed as it can be due to sequencing error (Table 3 ).

Table 3

Summary of Singleton OTUs

\begin{tabular}{lc}
\hline Total Reads & 186,667 \\
Total OTUs Picked & 4,361 \\
Total Singleton OTUs & 2,362 \\
$\begin{array}{l}\text { Total OTUs after Single- } \\
\text { ton removal }\end{array}$ & 1,999 \\
\hline
\end{tabular}

'QIIME program' was used for the entire downstream analysis. Representative sequence was identified for each OTU and aligned against Greengenes core set of sequences using 'PyNAST program'. Further, we aligned this representative sequences against reference chimeric data sets. Then, taxonomy classification was performed using RDP classifier and Greengenes OTUs database. The phylum, class, order, family, genus and species distribution for each sample based on OTU and reads are shown in Fig. 2.
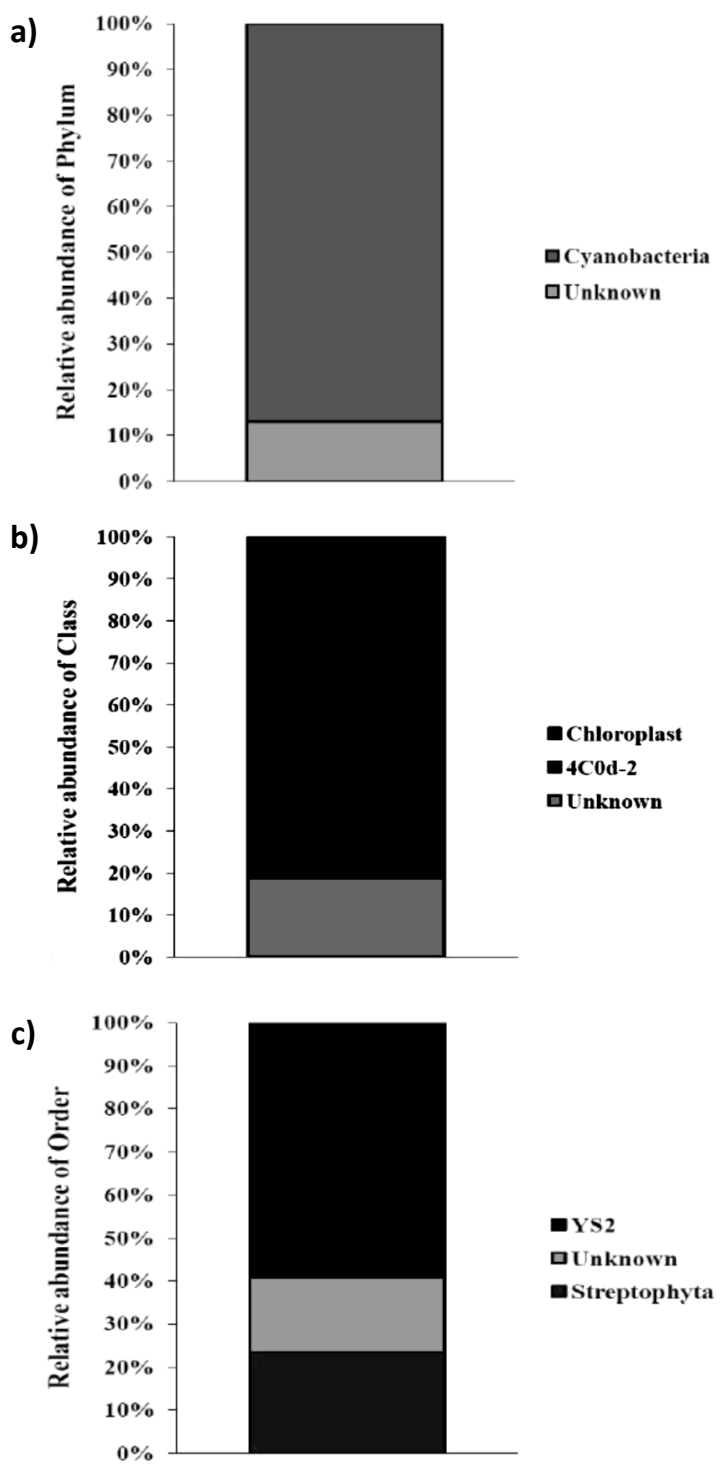

Fig. 2 Relative abundance of the OTUs at the: a) phylum, b) class and c) order levels across the anaerobically screened $P B$ medium

\section{Gas composition analysis}

During analysis of the product gas, samples were collected regularly after one week interval and their calorific values were measured using standard instruments. Each time we have found a drastic change in volume and calorific value in presence of anaerobic cyanobacterial culture. The Gas Chromatographic (GC) analysis of gas samples also revealed the volume increase of methane and hydrogen in addition with percent decrease of carbon dioxide in the gas mixture. Results are shown below in a tabulated manner in Table 4. 
Table 4

Fuel gas generation by cyanobacteria present in PB screened culture media from fresh cow dung

\begin{tabular}{|c|c|c|c|c|c|c|c|c|c|}
\hline $\begin{array}{c}\text { Slurry } \\
\text { description }\end{array}$ & $\mathrm{pH}$ & $\begin{array}{l}\text { BOD } \\
(g / L)\end{array}$ & $\begin{array}{l}\text { COD } \\
(g / L)\end{array}$ & $\begin{array}{l}\text { VS } \\
(\mathrm{g} / \mathrm{L})\end{array}$ & $\begin{array}{c}\text { Total } \\
\text { Vol. of } \\
\text { product } \\
\text { gas } \\
\text { (in } \mathrm{ml} \text { ) } \\
\end{array}$ & $\begin{array}{c}\text { Gas } \\
\text { starts } \\
\text { burning } \\
\text { (after days) }\end{array}$ & $\begin{array}{l}\text { Hydraulic } \\
\text { retention } \\
\text { time (HRT) } \\
\text { (in month) }\end{array}$ & $\begin{array}{c}\text { Gas } \\
\text { composition } \\
\text { (in ml) } \\
{\left[\mathrm{H}_{2} / \mathrm{CH}_{4} / \mathrm{CO}_{2}\right]}\end{array}$ & $\begin{array}{c}\text { Calorific } \\
\text { value } \\
\left(\text { in }^{\circ} \mathrm{C}\right)\end{array}$ \\
\hline $\begin{array}{l}\text { Cow dung slurry } \\
\text { (without } \\
\text { autoclaved) }\end{array}$ & 6.2 & 4220 & 5880 & 5200 & 7050 & 15 & 3 & $\begin{array}{c}688.79 / 3900.06 / \\
2249.66\end{array}$ & 720 \\
\hline $\begin{array}{l}\text { Autoclaved cow } \\
\text { dung slurry }+ \\
\text { anaerobically } \\
\text { screened PB } \\
\text { medium }\end{array}$ & 5.9 & - & - & - & 10700 & 12 & 3 & $\begin{array}{c}1085.87 / \\
7475.64 / 1883.20\end{array}$ & 860 \\
\hline
\end{tabular}

\section{DISCUSSION}

There are numerous reports on cyanobacterial biofuelation abilities [21]. In this experimental study, we have rechecked cynobacterial gaseous fuels (like; hydrogen and methane) generation ability in addition with carbon dioxide assimilation capability through photosynthesis i.e., biological visiblephoton absorption or Biophotonics. Photosynthetic bacteria are nature made 'anode' that can convert visible-photon's energy to bioelectricity and biohydrogen [22]. From gas chromatographic (GC) analysis we have found hydrogen within the fuel gas mixture. Cyanobacteria produce carbon dioxide during anaerobic digestion but that carbon dioxide is reduced by hydrogen produced during photosynthesis and methane percentage as well as flame temperature of the fuel gas increases to $860^{\circ} \mathrm{C}$, higher than liquid petroleum gas (LPG; flame temperature $750-760^{\circ} \mathrm{C}$ ).

'V3-Metagenomeics' identifies cyanobacteria from the orders YS2 and Streptophyta as active fuel gas producers (Fig. 2). Gas chromatographic analysis of volatile fatty acids (VFAs) reveals the high levels of straight chain fatty acids like; formate $(2288.11 \mathrm{mg} / \mathrm{L})$, propionate $(2668.9 \mathrm{mg} / \mathrm{L})$, butyrate $(1233.3 \mathrm{mg} / \mathrm{L})$ and 'most interesting' gluconate $(1093.9 \mathrm{mg} / \mathrm{L})$ than in normal cow dung slurry (formate: $1632.21 \mathrm{mg} / \mathrm{L}$; propionate $1461.7 \mathrm{mg} / \mathrm{L}$ and butyrate $1123.9 \mathrm{mg} / \mathrm{L}$ but no gluconate).

Presence of high level of VFAs in the cyanobacterial digestion makes $\mathrm{pH}$ of the slurry acidic $(\mathrm{pH}=5.9)$ than normal digestion $(\mathrm{pH}=6.2$ ) (Table 4). As VFAs are believed as the indicator of the reactor then presence of gluconate in the cyanobacterial digested slurry indicates cyanobacterial photosynthesis inside the photo-anaerobic digester. For this, we have found only $17.6 \%$ carbon dioxide in the fuel gas mixture produces by cyanobacterial community only while, anaerobic digestion by all cow dung microbiome produces gas mixture with $31.9 \%$ carbon dioxide.

Reculture of the cyanobacterial community from the digested slurry after the determined hydraulic retention time (HRT = 3 months) has been successfully carried out by using the methods describe above. Identification of the cyanobacterial community does not show any contamination due to using of specific culture media, PB. So, one-time cyanobacterial isolation may reuse in several next Times as digested-slurry inoculums and common people do not feel any problem during fuel generation.

The techniques have been used in the making of photoanaerobic digester is so simple and not beyond the knowledge and physical strength of single man. Common people can build it easily in their home as per their daily energy requirement. Reuses of environment hazard 'waste plastic mineral bottles' may also be an important technique for environment pollution control in future. This photobioreactor may also help in sustainable development in energy sector by producing 'green energy' through algal or bacterial photosynthesis and percent decrement of greenhouse gas $\mathrm{CO}_{2}$.

\section{CONCLUSIONS}

Photosynthetic bacterial application in biofuel production, is again proved a successful method of greenhouse gases sequestration. The result obtained, in this experimental study using a special group of bacterial community may vary if, another group of bacterial community is used. But this laboratory scale method of biomass conversion will show direction how waste biomass can be utilized to generate valuable fuel gas in commercial scale. This result may also very if, other cattle manure will use.

\section{ACKNOWLEDGEMENT}

We are highly thankful to prof. dr hab. Grażyna Płaza, Mikrobiologia Środowiska, Zakład Badań i Rozwoju for her kind attention and advices on this article.

\section{REFERENCES}

[1] G. Rana, T. Mandal, N.K. Mandal and S. Mandal, "Hydrogen containing fuel gas generation from organic wastes using photon activated magnesium metal catalyst", South African Journal of Chemical Engineering, vol. 23, pp. 124-131, 2017.

[2] J. Wang, "Decentralized biogas technology of anaerobic digestion and farm ecosystem: opportunities and challenges", Frontiers in Energy Research, vol. 2, no. 10, pp. 1-12, 2014.

[3] T. Mandal, B.A. Kiran and N.K. Mandal, "Determination of the quality of biogas by flame temperature measurement", Energy Conversion \& Management, vol. 40, pp. 1225-1228, 1999.

[4] T. Stalin, B. Sathya Priya and K. Selvam, "Ecofriendly application of cellulase and xylanase producing marine Streptomyces clavuligerus as enhancer in biogas production from waste", African Journal of Environmental Science and Technology, vol. 6, no. 6, pp. 258-262, 2012.

[5] F.W. Ntengwe, L. Njovu, G. Kasali and L.K. Witika, "Biogas production in cone-closed floatingdome batch digester under tropical conditions", International Journal of ChemTech Research, vol. 2, pp. 483-492, 2010. 
[6] T. Mandal, N.K. Mandal and V. Rao, "Comparative study of biogas production from different waste materials", Energy Conversion \& Management, vol. 38, pp. 679-683, 1997.

[7] A. Mudhoo, P.R. Moorateeah and R. Mohee, "Effects of Microwave Heating on Biogas Production, Chemical Oxygen Demand and Volatile Solids Solubilization of Food Residues", World Academy of Science, Engineering and Technology, vol. 69, pp. 805-810, 2012.

[8] T. Mandal and N.K. Mandal, "Biomethanation of some waste materials with pure metallic magnesium catalyst: improved biogas yields", Energy Conversion \& Management, vol. 39, pp. 1177-1179, 1998.

[9] M.S. Miah, C. Tada, Y. Yang and S. Sawayama, "Aerobic thermophilic bacteria enhance biogas production", Journal of Material Cycles and Waste Management, vol. 7, no. 1, pp. 48-54, 2005.

[10] M.A. Abdel-Hadi, "Determination of methane content by measurements of flame temperature and voltage from biogas burner", Misr Journal of Agricultural Engineering, vol. 26, pp. 498-513, 2009.

[11] M. Kröbera, T. Bekel, N.N. Diazb, A. Goesmann, S. Jaenicke, L. Krause, D. Miller, K.J. Runte, P. Viehöver, A. Pühler and A. Schlüter, "Phylogenetic characterization of a biogas plant microbial community integrating clone library 16S-rDNA sequences and metagenome sequence data obtained by 454-pyrosequencing", Journal of Biotechnology, vol. 142, pp. 38-40, 2009.

[12] N.N. Tuan, Y.C. Chang, C.P. Yu and S.L. Huang, "Multiple approaches to characterize the microbial community in a thermophilic anaerobic digester running on swine manure: A case study", Microbiology Research, vol. 169, no. 9-10, pp. 717-724, 2014.

[13] M.L. Chong, N.A.A. Rahman, R.A. Rahim, S.A. Aziz, Y. Shirai and M.A. Hassan, "Optimization of biohydrogen production by Clostridium butyricum EB6 from palm oil mill effluent using response surface methodology", International Journal of Hydrogen Energy, vol. 34, no. 17, pp. 7475-7482, 2009.

[14] N. Quintana, F. van der Kooy, M.D. Van de Rhee, G.P. Voshol and R. Verpoorte, "Renewable energy from Cyanobacteria: energy production optimization by metabolic pathway engineering", Applied Microbiology Biotechnology, vol. 91, no. 3, pp. 471-490, 2011.

\section{dr. Gopinath Rana}

Biochemist and R\&D Associate

Venkatesh Natural Extract Pvt. Ltd.

Madhyapradesh, INDIA

e-mail: ranagbcm@gmail.com

Prof. Tanusri Mandal

Bioconversion Laboratory, Department of Biotechnology, Vidyasagar University, West Bengal, INDIA
[15] L. You, L. He and Y.J. Tang, "Photoheterotrophic Fluxome in Synechocystis sp. Strain PCC 6803 and Its Implications for Cyanobacterial Bioenergetics", Journal of Bacteriaology, vol. 197, no. 5, pp. 943-950, 2015.

[16] G. Rana, T. Mandal and N.K. Mandal, "Generation of high calorific fuel gas by photosynthetic bacteria isolated from cowdung", International Journal of Research (IJR), vol. 1, no. 8, pp. 115-128, 2014.

[17] Y. Huang, L. Zhao, T. Dong and X. Tan, "Optimization of enzyme - producing conditions of Micrococcus sp. $S$ -II for L-Cysteine production", African Journal of Biotechnology, vol. 10, pp. 615-623, 2010.

[18] V.L. Webb and E.W. Maas, "Sequence analysis of $16 \mathrm{~S}$ rRNA gene of cyanobacteria associated with the marine sponge Mycale (Carmia) hentscheli", FEMS Microbiology Letters, vol. 207, no 1, pp. 43-47, 2002.

[19] J.G. Caporaso, J. Kuczynski, J. Stombaugh, K. Bittinger, F.D. Bushman, E.K. Costello, N. Fierer, A.G. Peña, J.K. Goodrich, J.I. Gordon, G.A. Huttley, S.T. Kelley, D. Knights, J.E. Koenig, R.E. Ley, C.A. Lozupone, D. McDonald, B.D. Muegge, M. Pirrung, J. Reeder, J.R. Sevinsky, P.J. Turnbaugh, W. A. Walters, J. Widmann, T. Yatsunenko, J. Zaneveld and R. Knight, "QIIME allows analysis of high-throughput community sequencing data", Nature Methods, vol. 7, pp. 335-336, 2010.

[20] M. Timmerman, E. Schuman, M. Van Eekert and J. van Riel, "Optimization the performance of a reactor by reducing the retention time and addition of glycerin for anaerobically digested manure", Environmental Technology, vol. 36, no. 10, pp. 1223-1236, 2015.

[21] D. Dutta, D. De, S. Chaudhuri and S.K. Bhattacharya, "Hydrogen production by Cyanobacteria", Microbial Cell Factories, vol. 4, no. 36, pp. 1-11, 2005.

[22] M. Rosenbaum, Z. He and L.T. Angenent, "Light energy to bioelectricity: photosynthetic microbial fuel cells", Current Opinion in Biotechnology, vol. 21, no. 3, pp. 259-264, 2010. 